\title{
Tissue Culture Propagation of Yam In Puerto Rico $^{1}$
}

\author{
Amelia Cortés-Monllor and Lii-Jang, Liü2
}

\begin{abstract}
Rapid propagation of yam (Dioscorea rotundata cv. Habanero) was obtained from nodal segments cultured in modified Murashige and Skoog medium containing indoleacetic acid (IAA) and kinetin as establishment medium, and naphthaleneacetic acid (NAA) as rooting medium. The proliferation cycle, which takes approximately $2-3$ months, increased four times the production of yam plantlets. These plantlets were successfully transferred to potting mixture and soil. This procedure is extremely useful for regenerating virusfree plantlets suitable for producing healthy tubers for planting.
\end{abstract}

\section{INTRODUCTION}

Habanero (D. rotundata Poir.) and Florido (D. alata L.) are some of the edible yams in Puerto Rico. They are not widely cultivated because they are costly to produce. Of the 30,835 kilograms of Habanero and 20,138 kilograms of Florido produced per hectare, $10,320 \mathrm{~kg} / \mathrm{ha}$ of Habanero and 4,881 kg/ha of Florido are used as seed-pieces (4). Approximately a third of the total marketable crop is reserved for planting purposes. Furthermore, it is estimated that $20 \%$ of the local yam plantings ${ }^{3}$ are being affected by virus diseases $(1,15,17)$. Propagation of maladies through seed-pieces increased rapidly. Research to improve quality of yam tubers, to reduce production costs, and to solve storage problems is urgently needed. Tissue culture technique has been widely used in many countries to produce disease-free planting material of potatoes (16), cassava (6), banana (3), yams (12) and others. Litz and Conover induced plantlet proliferation of papaya (8) and sweet potato (9) by adding kinetin, IAA, NAA and benzyladenine (BA) or their combination in different concentrations. In Puerto Rico, Alconero in 1975 (2) reported the response of local sweet potatoe cultivars to auxin combinations. Our efforts were conducted to develop a rapid yam propagation system by using tissue culture method by which, eventually, disease-free yam plantlets could be selected for producing yams of good quality and yield. Mantell, in Trinidad $(10,11)$ obtained good results in yam tissue culture with $\mathrm{M} \& \mathrm{~S}$ basal medium without adding growth

${ }^{1}$ Manuscript submitted to Editorial Board August 26, 1982.

${ }^{2}$ Associate Bacteriologist and Phytopathologist, respectively, Department of Crop Protection, Agricultural Experiment Station, College of Agricultural Sciences, University of Puerto Rico, Mayagüez Campus, Río Piedras, P.R. Supported in part by USDA, Cooperative Agreement No. 58-7B39-9-115 (TAD Research Grant).

${ }^{3}$ López-Rosa, J. H., personal communication. 
regulators. Previously, in the 1973 Nigeria IITA Report (5), the use of kinetin $(4 \mathrm{mg} / \mathrm{l})$ to initiate shoot differentiation of yam was mentioned. This paper reports a procedure developed for a rapid propagation of $D$. rotundata cv. Habanero in Puerto Rico.

\section{MATERIALS AND METHODS}

Dioscorea rotundata cv. Habanero seed-pieces were pre-conditioned in the greenhouse for 2-6 months before the vines were used for tissue culture. Nodal segments with lateral buds (fig. 1) were cut into sections of $0.5-1 \mathrm{~cm}$ and were immediately immersed in distilled water for a few minutes prior to surface sterilization.

Surface sterilization was carried out under aseptic conditions in a microvoid chamber. Alcohol (95\%) and commercial Clorox ${ }^{4}$ in 1:1 proportion were used for surface sterilization. Excised segments were dipped

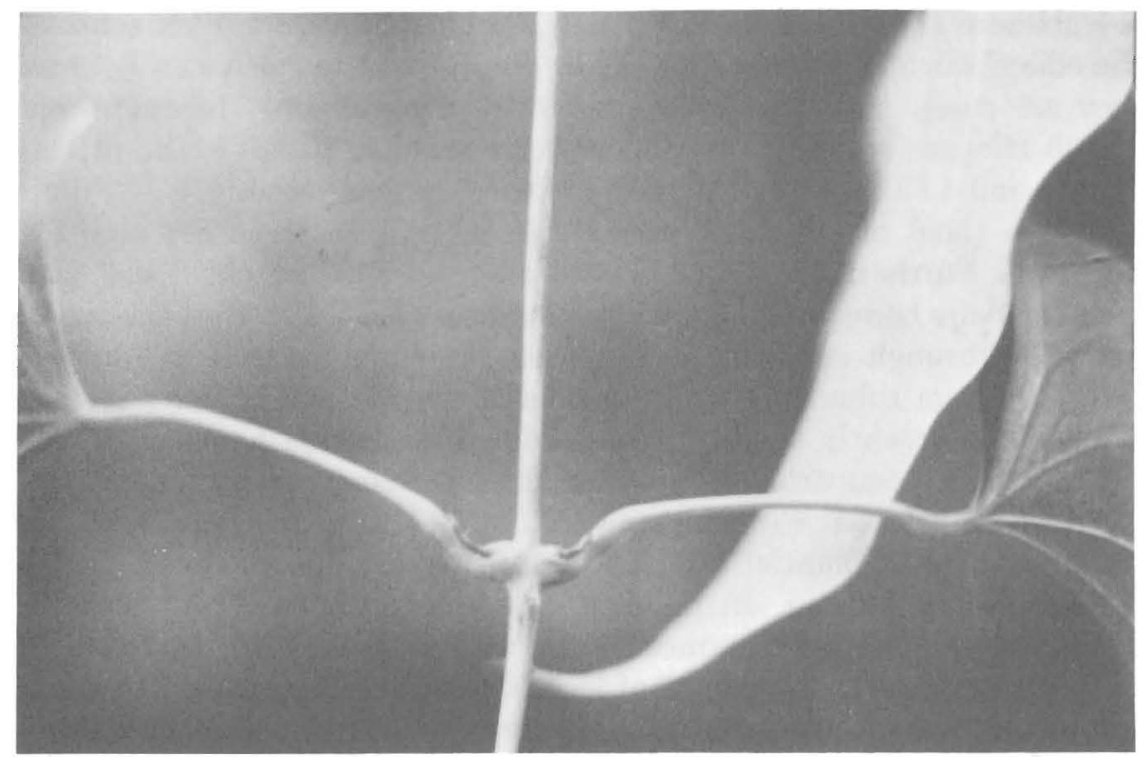

FiG. 1.-D. rotundata cv. Habanero nodal segment with growing buds.

in the solution with constant agitation for 5-7 min., rinsed three times in double distilled sterile water, and finally transferred to a sterile petri dish with filter paper to absorb excess water before being placed in the culture medium.

${ }^{4}$ Trade names in this publication are used only to provide specific information. Mention of a trade name does not constitute a warranty of equipment or materials by the Agricultural Experiment Station of the University of Puerto Rico, nor is this mention a statement of preference over other equipment or materials. 
Murashige and Skoog (M \& S) basal culture medium (14) was modified by increasing sucrose content to $30 \mathrm{~g} / \mathrm{L}$, agar to $8 \mathrm{~g} / \mathrm{L}$, and by adding growth regulators kinetin and IAA ( $2 \mathrm{mg} / \mathrm{L}$ of each) for establishment medium and NAA ( $1 \mathrm{mg} / \mathrm{l})$ for rooting medium, as shown in the following tabulation:

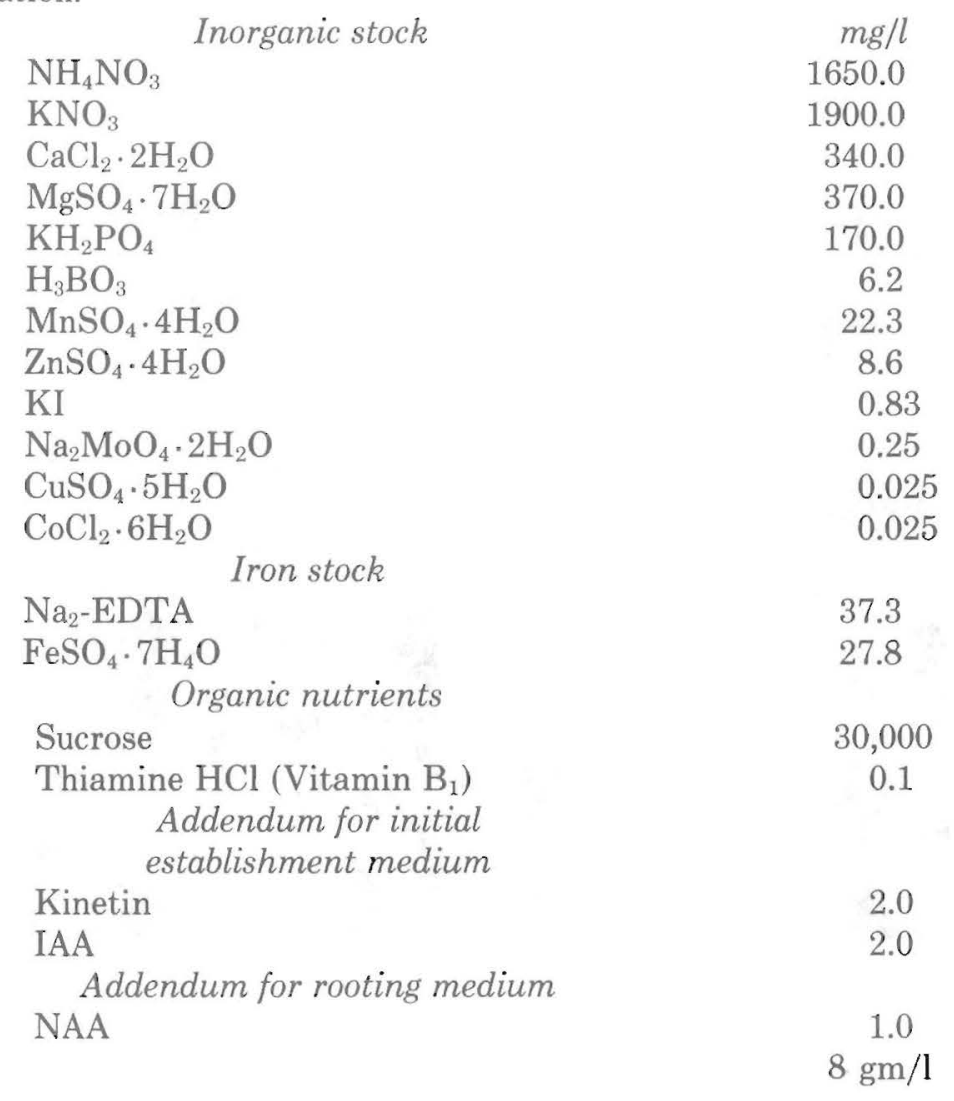

The iron stock solution contained $0.746 \mathrm{~g} \mathrm{Na}$-EDTA and $0.556 \mathrm{~g}$ $\mathrm{FeSO}_{4} \cdot 7 \mathrm{H}_{2} \mathrm{O}$ in $200 \mathrm{ml}$ distilled water. Five $\mathrm{ml} / \mathrm{l}$ of the stock solution was added to the basic medium. The $\mathrm{pH}$ was adjusted to $5.8-6.0$ with $\mathrm{N}$ $\mathrm{NaOH}$. Aliquots of $10 \mathrm{ml}$ were dispersed in culture vials for autoclaving at $121^{\circ} \mathrm{C}, 1 \mathrm{~kg} / \mathrm{cm}^{2}$ pressure for $15 \mathrm{~min}$. Media were stored at room temperature for $24 \mathrm{~h}$ before use.

Nodal segments, cultures and plantlet vials were incubated under light intensity of $12-14,000$ lux for a $16-\mathrm{hr}$ period at $26-28^{\circ} \mathrm{C}$.

Rooted plantlets were carefully removed from vials and transferred to petri dish containing tap water to remove excess of the agar medium adhered to the roots. In many cases two rinses were necessary. Plantlets 
were seeded in a wet sterile potting mixture (commercial Pro-mix) ${ }^{4}$ contained in $485-\mathrm{cm}^{3}$ flats (fig. 2). The uncovered trays containing plantlets were placed in the greenhouse and watered after 3 to 4 days. Nutri-leaf fertilizer was added twice in the 3-mo period from the time plantlets were transplanted to $30-\mathrm{cm}$ pots containing sterile soil until harvest (fig. 3). Insect control was accomplished by spraying every week with a mixture of Diazinon $(10 \mathrm{ml} / \mathrm{gal})$ and Kelthane $(5 \mathrm{mg} / \mathrm{gal})$ and/or Malathion (10 ml/gal) and Kelthane $(5 \mathrm{mg} / \mathrm{gal})$.

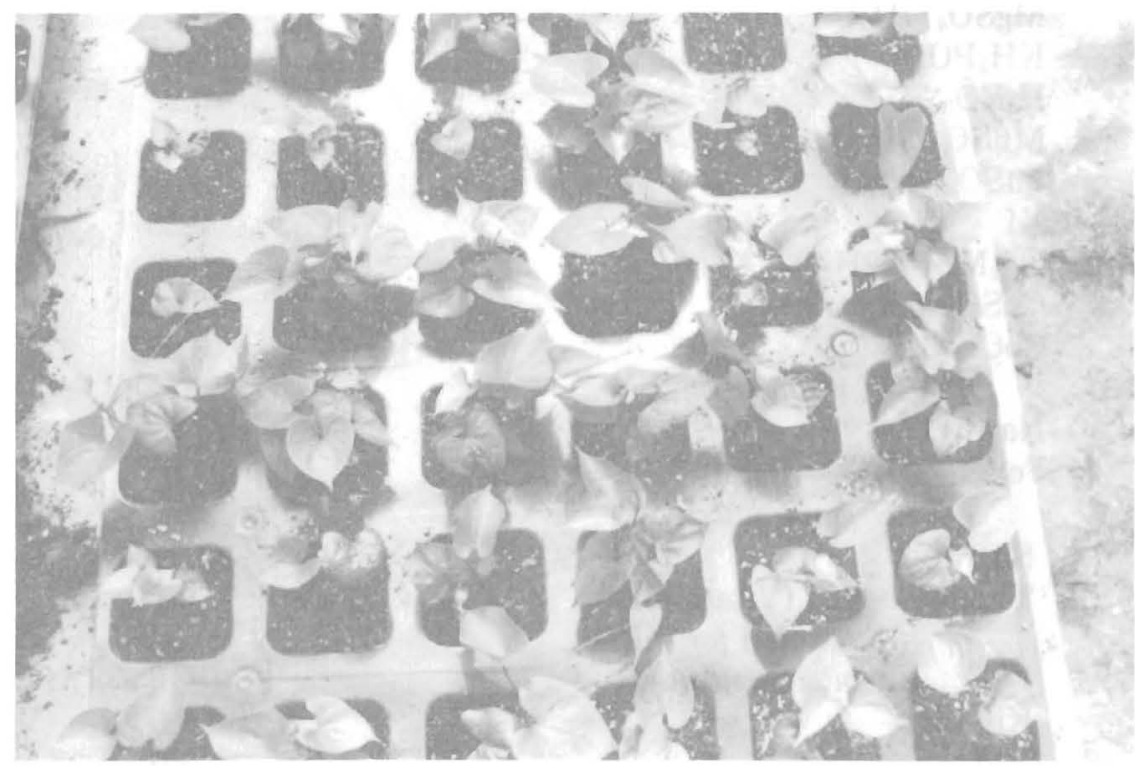

FIG. 2.-Plantlets seeded in trays with potting mixture, 2 months old.

\section{RESULTS AND DISCUSSION}

A procedure for rapid propagation of yam plantlets was developed. Nodal segments of $D$. rotundata $\mathrm{cv}$. Habanero regenerated plantlets when seeded on modified M \& S medium supplemented with growth regulators kinetin and IAA for proliferation of leaves, and NAA for root development. Initial experiments showed contamination and slight oxidation as major problems. At first, excised segments were washed in running water for a few hours before sterilization. When the whole process was finished, oxidizing effect was noticed within $24 \mathrm{~h}$ or contaminants appeared in 1 to 3 days. Of the various disinfectants tried ( $3 \%$ Lysol, 1-2 min; zephiran chloride 1:1000 solution, 1-2 min.; 10\% Clorox, 1-6 min.; and 70\% 


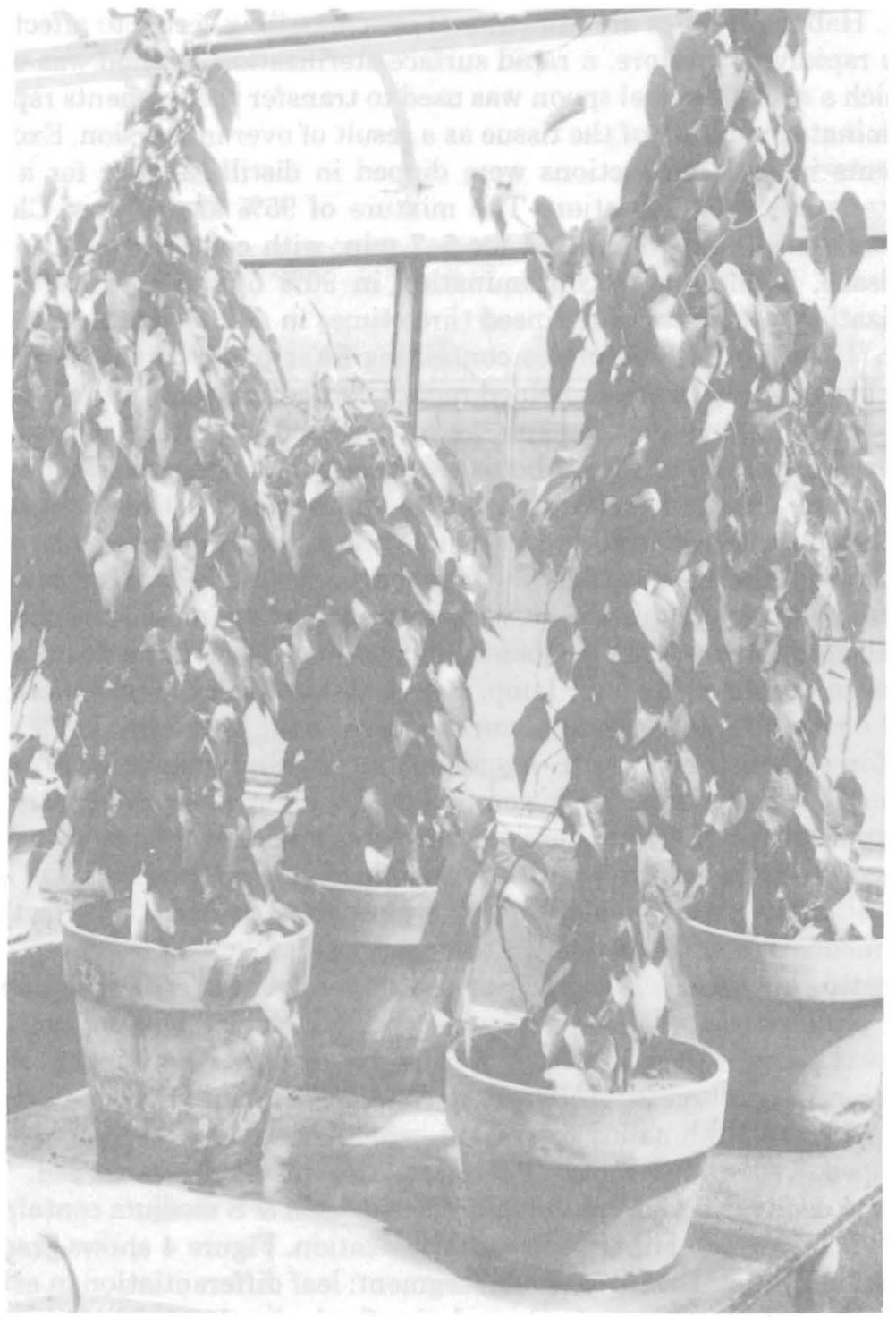

FIG. 3.-Mature Habanero plants.

alcohol, 1-2 min.), none inhibited contaminant growth properly. All had toxic effects. Some bactericides and fungicides were also tried without success. Actidione at $0.02 \%$ and sodium azide at $1 / 40$ dilution reduced contamination, but no growth was observed, probably because of toxic 
effect. Habanero vines are tender, and over-handling seems to affect the tissue rapidly. Therefore, a rapid surface sterilization method was used, in which a stainless steel spoon was used to transfer the segments rapidly to eliminate oxidation of the tissue as a result of over immersion. Excised segments in .5-1 cm sections were dipped in distilled water for a few minutes prior to sterilization. The mixture of $95 \%$ alcohol and Clorox (1:1) was tried, and when used for $5-7 \mathrm{~min}$. with constant agitation of the tissue, it eliminated contamination in $90 \%$ of the cultures. After sterilization, segments were rinsed three times in sterile, double-distilled water. The use of sterile plates containing filter paper to absorb excess of water from the segments helped reduce contamination. In some cases, when numerous nodal segments were processed, a second filter paper plate was used. To insure a better sterilization process, solutions and plates were changed frequently. At the initiation of this project no laminar flow was available and the whole procedure was carried out under a microvoid chamber, which we sprayed occasionally with alcohol to maintain aseptic conditions. Instruments such as stainless steel spoons, scalpels and forceps were frequently dipped in alcohol, flamed and allow to cool under an ultraviolet lamp. Segments seeded in vials containing $10 \mathrm{ml}$ of $\mathrm{M} \& \mathrm{~S}$ medium supplemented with $2 \mathrm{mg} / \mathrm{l}$ kinetin and $2 \mathrm{mg} / \mathrm{l}$ IAA for establishment were incubated in growing chambers. Various tissue culture media $(3,7,9)$ were tested for plantlet establishment. In our experiments, the Habanero segments responded very slowly to $\mathrm{M}$ \& $\mathrm{S}$ basal medium without growth regulators. Some proliferation was observed after 1 mo in culture. At the most we obtained $62 \%$ growth in 2 mo incubation without root formation.

Kinetin and IAA (0.5-2 mg/l of each) were evaluated for Habanero nodal proliferation. The best responses were obtained when $2 \mathrm{mg} / \mathrm{L}$ of each was added to the medium. Within 10-15 days of culturing, shoot induction was observed. Addition of NAA in combination with kinetin and IAA resulted in callus formation, which eventually and very slowly developed leaves and roots. Therefore, two media were needed. The shoots were divided and individually seeded on M \& S medium containing $1 \mathrm{mg} / \mathrm{l} \mathrm{NAA}$, which enhanced root proliferation. Figure 4 shows gradual development from the initial nodal segment: leaf differentiation in establishment medium (stages 1-4), and the final plantlet production with abundant proliferation of roots in rooting medium (stages 5-8) within 3months propagation cycle.

In some cases we observed both shoots and root formation in the initial establishment medium. Similar effects on in vitro growth responses of D. alata were described by Mantell (10) and those on D. floribunda and D. composita nodal cuttings were described by Martin and Delpín (13). 
Growth responses in $D$. rotundata may differ according to age as well as maturity of the nodal segments in the same vine.

Plantlet production was consistently best induced from 2-6 month-old nodal segments. Vines of younger plants were immature, and in many cases plantlets did not develop. Nevertheless, 113 plantlets were obtained in the potting mixture from 10 cultured segments of such vines in a 10month period. The greatest increase in production was obtained when segments from 3-5-month-old plants were used. Of the 500 cultured segments, over 2,000 plants were obtained within a 5-month period. Even after 18 months from initial culture, shoots can still be further divided

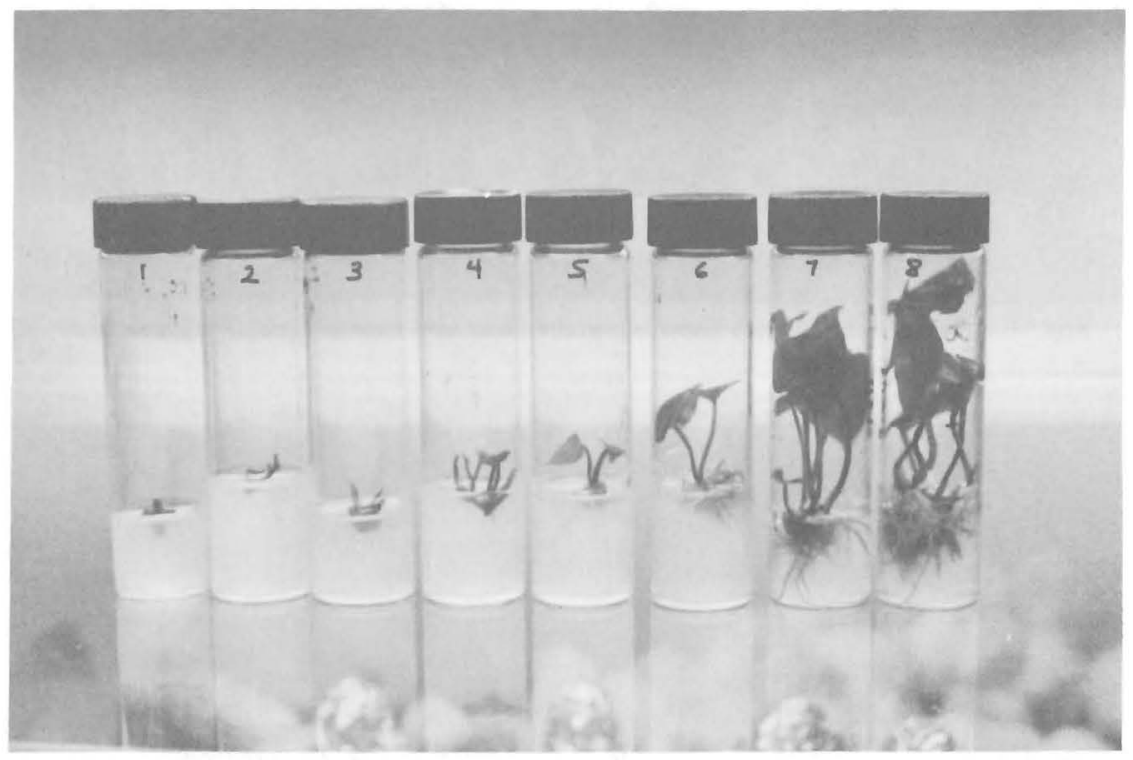

FIG. 4.-Propagation cycle, 1-4; establishment medium, initial nodal segment and leaf proliferation; 5-8: rooting medium, plantlet division, initial root development and regenerated plantlet ready for potting mixture.

to increase the desired number of plantlets for potting. Throughout the experiment we also observed that 7-month-old segments were slower in their growth responses, and thus production of plantlets was reduced.

Various patterns in yam shoot development were observed. Some of these multi-leaved, a condition which facilitated division, while others regenerated into plantlets with $2-4$ nodal segments. These were divided or cut accordingly and seeded in establishment medium. In this way, the rate of multiplication was tripled every 3 months. When the desired number of plantlets was obtained, mostly 1-2 inches high, with good proliferation of roots, they were carefully removed from the culture media, 


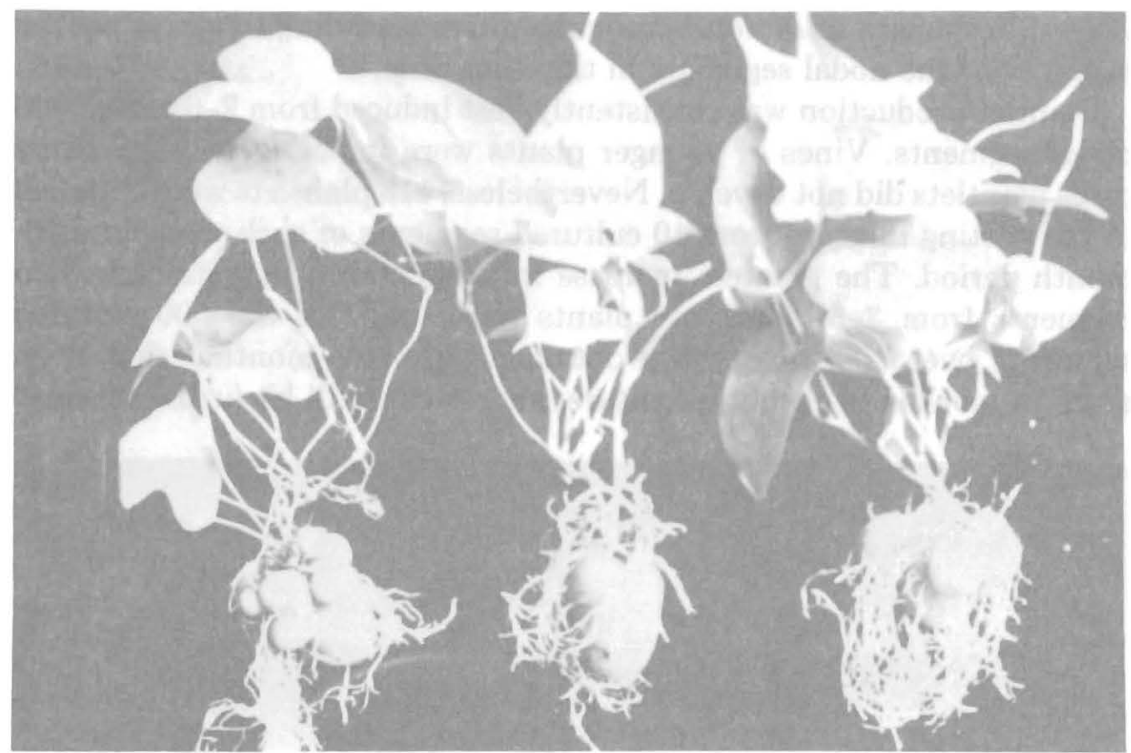

FIG. 5.-Habanero plantlets showing seed tubers and root system development at 3-4 months in potting mixture.

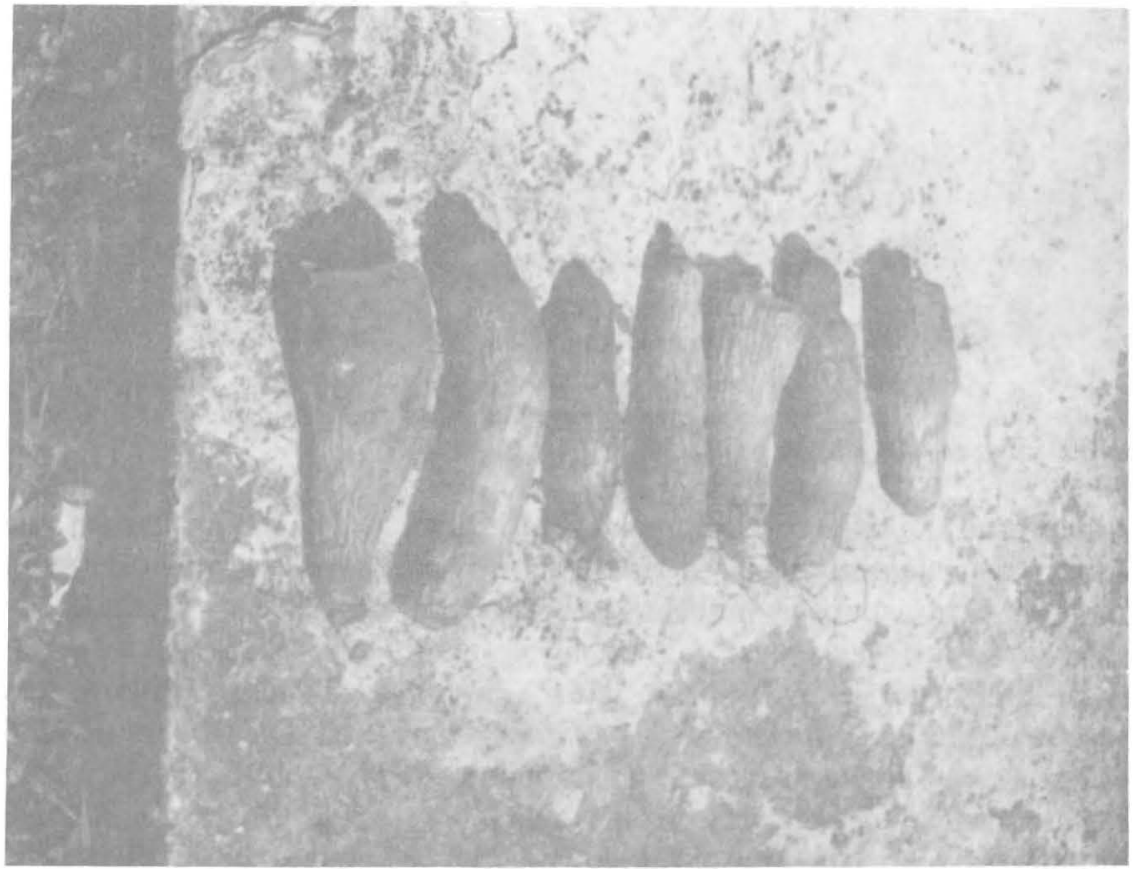

FIG. 6.-Tubers harvested from mature Habanero plants originated from tissue culture. 
the agar was washed off, and they were planted in a sterile potting mixture in the greenhouse. Commercial Pro-mix was found suitable for yam plantlets. It is composed of equal parts of sphagnum, peat moss, horticultural vermiculite, and perlite plus enough major and minor elements for intitial growth. It can be re-sterilized for further use. Trays containing plantlets were left uncovered usually for 3 months. The plantlets were fertilized twice. At this stage, the seedpieces weighed 6-10 $\mathrm{g}$, with healthy proliferation of roots (fig. 5).

Throughout the entire experiments we did not observe any variability in shape of leaves and vines of yam plantlets obtained from tissue culture. The selection of healthy plantlets was based on visual examination of disease-free leaves. These plantlets were suitable for transplanting, ensuring good-sized tubers for commercial planting (fig. 6). These selections for propagation can initially control virus dissemination and improve the quality and yield of yam. Undoubtedly, it would also alleviate the seed shortage, thus reducing the cost of local yam production.

\section{RESUMEN}

Se estableció un ciclo de propagación rápida del ñame $D$. rotundata cv. Habanero. La siembra de segmentos en el medio de cultivo de Murashige y Skoog con IAA, cinetina y NAA, como nutrimentos reguladores de crecimiento, aumentó cuatro veces la producción de plántulas libres de enfermedades en un término de 3 meses. Estas plántulas se transplantaron y crecieron normalmente en musgo y tierra. Este procedimiento es de gran utilidad en la producción de material de propagación selectivo, libre de enfermedades, para la siembra. Además, restringiría la diseminación de virus por el material corriente de propagación, aumentaría la calidad y el rendimiento del ñame, a la vez que reduciria tanto el costo de producción como el precio de venta.

\section{LITERATURE CITED}

1. Adsuar, J., 1955. A mosaic disease of the yam, Dioscorea rotundata, in Puerto Rico. J. Agric. Univ. P. R. 39 (3): 111-3.

2. Alconero, R., A. G. Santiago, F. Morales, and F. Rodriguez, 1975. Meristem tip culture and virus indexing of sweet potatoes, Phytopathology 65 (7): 769-73.

3. Berg, L. A. and M. Bustamante, 1974. Heat treatment and meristem culture for the production of virus-free bananas, Phytopathology 64: 320-2.

4. González-Villafañe, E., G. R. Espinet, and J. L. Troche-Ducot, 1980. Análisis económico de la producción de ñames en Puerto Rico, Esta. Exp. Agric. Univ. P.R., Publicación 132.

5. IITA, (1974). Root and tuber improvement program. In Annual Report 1973, Int. Inst. Trop. Agric., Ibadan, Nigeria.

6. Kartha, K. K. and O. L. Gamborg, 1975. Elimination of cassava mosaic disease by meristem culture, Phytopathology 65:826-8.

7. Linsmaier, E. M. and F. Skoog, 1965. Organic growth factor requirements of tobacco tissue culture, Physiol. Plant. 18: 100-27. 
8. Litz, R. E. and R. A. Conover, 1978. In vitro propagation of papaya, Hort. Sci. 13 (3): $241-2$.

9. — and — 1978. In vitro propagation of sweet potato, Hort. Sci. 13 (6): 659-60.

10. Mantell, S. H., S. Q. Haque, and A. P. Whitehall, 1978. Clonal multiplication of Dioscorea alata L. and Dioscorea rotundata Poir. yams by tissue culture, J. Hort. Sci. 53 (2): 95-8.

11.___ and _ 1979. A rapid propagation system for yam, Caribbean Agric. Res. Dev. Inst. Univ. Campus, St. Augustine, Trinidad. Yam Virus Project Bulletin no. 1.

12. — - - and - 1980. Apical meristem tip culture for eradicaton of flexuous rod viruses in yams (Dioscorea alata), Trop. Pest Manage. 26 (2): 170-9.

13. Martin, F. W. and H. Delpin, 1969. Techniques and problems in the propagation of sapogenin-bearing yams from stem cuttings. J. Agric. Univ. P.R. 53: 191-8.

14. Murashige, T. and F. Skoog, 1962. A revised medium for rapid growth and bioassays with tobacco tissue culture, Physiol. Plant. 15: 473-97.

15. Ruppel, E. G., H. Delpin, and F. W. Martin, 1966. Preliminary studies on a virus disease of sapogenin-producing Dioscorea species in Puerto Rico. J. Agric. Univ. P.R. 50: 151-7.

16. Shirvin, R. M., Shue-Lock Lam, and J. Janick, 1975. Plantlet formation from potato callus in vitro, Hort. Sci. 10 (4): 414-4.

17. Waterworth, H. E., R. H. Lawson and R. P. Kahn, 1974. Purification, electron microscopy, and serology of Dioscorea latent virus, J. Agric. Univ. P.R. 58 (3): $351-7$. 